\title{
IMPACT OF MIGRATION PROCESSES ON THE ECONOMIES OF WESTERN EUROPE
} ВПЛИВ МІГРАЦІЙНИХ ПРОЦЕСІВ НА ЕКОНОМІКИ КРАЇН ЗАХІДНОÏ ЄВРОПИ

The article analyzes factors influencing migration processes in the EU, namely in France, Belgium and the Netherlands, as well as their impact on the economies of the above states over the period 2009-2019. To identify the main reasons for immigration to these EU Member States, various indicators were considered, including macroeconomic indicators such as GDP, GDP per capita, tax rates, unemployment rates, employment rates among various segments of the population, as well as the socio-political situation in countries. The results show that social and political aspects are the key factors for emigrants from Africa, South Asia, Central America and Southeast Europe to selected EU countries, while economic factors are important for the rest of the European migrants. Therefore, migrants from poor countries, deciding to migrate to the $E U$, primarily pursue the goal of living in a safe and politically stable state, while emigrants from developed European countries migrate to get higher wages and better quality living conditions. The study also examines the impact of migrant remittances on the economies of recipient and destination countries. It was found that, despite the geographic location and similarity of economies, France and Belgium are net recipients of remittances, while the Netherlands is a net donor. Key words: migration, migrant remittances, France, Belgium, the Netherlands, European Union, asylum seekers, labor migrants, unemployment rate.

В статье рассматриваются фракторы, влияющие на миграционные прочессы в странах Европейского союза, а именно во Франции, Бельгии и Нидерландах, а также их влияние на экономики вышеперечисленных государств в период 2009-2019 годов.
Для выявления основных причин иммиграции в эти государства-члены ЕС были проанализированы различные показатели, в том числе макроэкономические, такие как ВВП, ВВП на душу населения, налоговые ставки, уровень безработицы, уровень занятости среди различных слоев населения, а также социально-политическая ситуация в странах. Результаты показали, что социальные и политические аспекты являются основными оракторами для эмигрантов из Асррики, Южной Азии, Центральной Америки и Юго-Восточной Европы в отдельные страны EC, в то время как для остальных европейских мигрантов наиболее важное значение имеют экономические фракторы. Полученные результаты свидетельствуют о том, что мигранты из бедных стран, решая мигрировать в ЕС, в первую очередь преследуют чель жить в безопасном и политически стабильном государстве, в то время как для эмигрантов из других европейских стран важнейшими аспектами являются получение более высокой заработной платы и более качественных условий жизни. В исследовании также проводится анализ влияния денежных переводов мигрантов на экономики странполучателей и стран назначения. Было выявлено, что, несмотря на свое географическое положение и схожесть экономик, Франция и Бельгия являются чистыми получателями денежных переводов мигрантов, а Нидерланды - чистым донором.

Ключевые слова: миграция, денежные переводы мигрантов, Франция, Бельгия, Нидерланды, Европейский союз, соискатели убежища, трудовые мигранты, уровень безработицы.

Economic Analysis and Finance
Ivan Franko National University of Lviv

Міжнародні міграційні процеси досі залишаються одним із чентральних питань для досліджень у системі міжнародних економічних відносин. Кількість мігрантів за останні 20 років зросла майже у два рази, що спричинило появу дисбалансів у багатьох національних економіках. У статті розглядаються фрактори, що впливають на міграційні процеси в країнах Європейського союзу, а саме у Франції, Бельгії та Нідерландах, які є країнами-реципієнтами, а також ї вплив на економіки вищеперелічених держав у 2009-2019 роках. Для виявлення основних причин імміграції в ці держави-члени ЄС були проаналізовані різні показники, в тому числі макроекономічні, такі як ВВП, ВВП на дуиу населення, податкові ставки, рівень безробіття, рівень зайнятості серед різних верств населення, а також соціально-політична ситуація в країнах. Також було досліджено вплив Міжнародного індексу щастя та рівня економічної нерівності у країнах перебування на рішення про міграцію. Результати показали, що соціальні та політичні чинники є основними фракторами для емігрантів з Асррики, Південної Азії, Центральної Америки і Південно-Східної Європи в окремі країни ЄС, в той час як для інших європейських мігрантів найбільш важливе значення мають економічні чинники. Отримані результати свідчать про те, що мігранти з бідних держав, вирішуючи мігрувати в країни ЄС, в першу чергу, мають на меті жити в безпечній та політично стабільній державі, в той час як для емігрантів з багатьох європейських країн найважливішими аспектами є отримання більш високої заробітної плати і якісніших умов життя. Також було виявлено, що ключовими фракторами імміграції до Бельгії та Нідерландів з інших країн ЄС є більш високі доходи та ВВП на душу населення, тоді як Франція в першу чергу приваблює високим рівнем освіти та забезпеченням високого ступеня захисту шукачів притулку, саме тому студенти та біженці займають приблизно 40\% усіх іммігрантів у країні. У дослідженні також проводиться аналіз впливу грошових переказів мігрантів на економіки країн-одержувачів і країн призначення. Було виявлено, що, незважаючи на своє географічне положення і схожість економік, Франція і Бельгія є чистими одержувачами грошових переказів мігрантів, а Нідерланди - чистим донором.

Ключові слова: міграція, грошові перекази мігрантів, Франція, Бельгія, Нідерланди, Європейський союз, біженці, трудові мігранти, рівень безробіття.

Problem statement. In the modern world, international migration processes are one of the key factors in the increasing interconnection of states and the integration of peoples; they have a huge impact on the economic state of countries. The recent European migration crisis (2015) introduced changes in the further development of not only the countries of
North Africa, the Middle East and South Asia, but also it affected the Member States of the European Union, that are among the main destination countries for foreign migrants. Therefore, many authors have paid considerable attention to the factors of migration and its impact on the economies of countries. However, at the moment, there are a few studies devoted to the 
motives of immigrants to the EU countries, especially France, Belgium and the Netherlands.

The goal of the research is to identify the main factors of migration processes in the European Union, as well as to investigate the impact of immigration flows and migrant remittances on such developed EU countries as France, Belgium and the Netherlands.

Literature review. M. Kahanec and M. Pytlikova (2016) explore connections between the immigration flows from the new EU Member States and the countries of destination as well as its effects on the economies of other EU countries in the late 20th early 21st century. The authors claim that the most attractive countries for destinations are highly developed states with successful economies, such as Germany, France, Malta, Netherlands, Norway, Finland, etc. Thus, it has been detected that there is an inversely proportional relationship between emigration from such Eastern countries as Ukraine, Moldova, Belarus, Armenia and Georgia to the EU and employment rate, GDP per capita along with GDP in host countries [1].

P.M. Orrenius and M. Zavodny (2016) consider the problems of illegal immigration to the EU drawing on lessons from the U.S. experience; the economic benefits for the receiving European countries and the immigrants themselves. Immigration to the EU countries for illegal migrants was fueled by large income gap, limited opportunities in countries of emigration, welfare programs in host countries and aging European population [2].

A. Strockmeijer, P. de Beer and J. Dagevos (2019) investigate temporary, circular and settlement migration from the countries of Central and Eastern Europe (CEE) to the Netherlands. The authors predict a new European migration, according to which there will be fewer labor migrants with continuous periods of work and more circular migrants [3].

G. Dominese, S. Yakubovskiy, J. Tsevukh, T. Rodionova (2020) present one of the latest relevant studies on international migration, paying particular attention to the flow of migrants to the EU during the recent years. The authors also consider the participation of Ukraine in this process and describe the migration implications for the country. Econometric analysis using a panel data structure reveals that the main drivers of the immigration process in the reviewed countries are GDP per capita and income level in host countries [4].

Many other studies are also devoted to the impact of international migration processes on the economies of different countries. Among them there are researches by J. Tsevukh [5], S. Yakubovskiy $[5 ; 6]$ and M. Kachanovska $[6 ; 7]$.

Presentation of the main material of the study. The largest emigration flows are recorded in France and the smallest are in Belgium. Moreover, during the period 2009-2018, the number of emigrants from the selected EU countries has increased significantly. Based on the fact that France, Belgium and the Netherlands are highly developed countries with fairly high GDP per capita, the factor of income is not the primary cause of emigration from these states. Top destinations for French expats include the UK, USA, Belgium, Spain and Switzerland. Mostly young and aged people emigrate from the country since this proportion of the population is most difficult to find work in France. Especially young people are under the threat of unemployment in France, almost 20\% of them are unemployed. Moreover, difficulties relating to starting a business also contribute to the French emigration. The flow of emigrants from Belgium is 4 times less than in France. The country's GDP per capita is 41.2 thousand EUR, and an hour of work is paid at 39.4 EUR, so it is more profitable to work in Belgium than in the other EU countries. First of all, Belgians leave their country not because of income or better living conditions, but because of their personal convictions.

The number of emigrants from the Netherlands increased relatively little compared to the other two analyzed countries - by $18.1 \%$ between 2009 and 2018. The state has a tendency to move to neighboring countries such as Belgium and Germany, and the Dutch are also emigrating to warmer climates such as Spain and Portugal. The incentives to move to another country are the lower taxation system and cheaper housing. The difference in personal income tax rates in the Netherlands, Germany and Belgium is not large, in these countries it is $52 \%, 50 \%$, and $45 \%$, respectively.

In 2018, the number of official immigrants to France was 4.8 million, which is $7.1 \%$ of the population of the entire country. There is a high level of education here, so students occupy a large share among all emigrants to France $-21.5 \%$ (83.000 people). Also, the country has a significant number of refugees, which is growing every year, the largest number of asylum seekers from Afghanistan, Albania and Georgia.

In 2018, Belgium recorded the largest number of migrants from France, Italy and the Netherlands. Basically, Belgians have a positive attitude towards immigrants from the EU Member States, which cannot be said about other ones. During the European Migration Crisis (2015), the number of immigrants to Belgium increased by $19 \%$ compared to the previous year, in France - by $7 \%$ and to the Netherlands by $15 \%$. The main motive for migration was family reunification, job search, higher income and education. However, in Belgium it is quite difficult for foreigners to get a job, as evidenced by a number of indicators. In 2017, the employment rate among migrants from countries that are not members of the EU was $52 \%$, among European immigrants it was 69\%, and for indigenous people - 72\% [8]. In addition, among all the EU countries, Belgium recorded the largest gap 
between the level of employment of citizens of the country and migrants from non-European countries.

The Netherlands, in contrast to Belgium, shows one of the highest employment rates among the EU countries $-80.5 \%$ of all native people are employed (higher only in Sweden - 85.5\% and Germany 81.6\%). The employment rate among migrants from non-EU countries is $60 \%$, and among immigrants from EU countries - 78\%. Steadily more migrants choose the Netherlands as a destination country, as it has a very high standard of living and high quality welfare systems. The largest proportion of immigrants come from Syria, Poland, Germany, India and the countries of the former Soviet Union. The economy of the Netherlands is one of the most open and strong economies in the EU, that is why this country attracts migrants even though there are a lot of taxes.

A positive migration rate has been recorded in France, Belgium and the Netherlands during the entire analyzed period (Figure 1). Since these countries show high performance according to various criteria, citizens of other European as well as non-European states immigrate to this very place. For instance, GDP per capita in the Netherlands in 2018 was 53 thousand EUR, while in Poland it is 3.5 times less, in Germany - 1.1 times less and in Italy - 1.5 times less. Excluding refugees, emigrants from these above countries predominate in the Netherlands.

The level of poverty in the country also affects migration flows. The share of the population at risk of poverty or social exclusion in France in 2017 was fixed at $17.1 \%$ (6th place among the EU), in the Netherlands - 17\% (4th place), and in Belgium $20.3 \%$ (13th place). At the same time, this indicator in the selected countries was below the average among the EU states, which was $22.4 \%$. This figure varies from $38.9 \%$ in Bulgaria to $12.2 \%$ in the Czech Republic. In Italy, $28.9 \%$ of the population is subjected to poverty and social exclusion, in Poland $-19.5 \%$, and in Germany - 19\%. Moreover, in all the EU Member States, women are more at risk of poverty, although in the Netherlands, France and Belgium this percentage is lower than in other countries.

It is difficult to accurately measure and analyze the level and quality of life in countries based only on key macroeconomic indicators, so it is appropriate to explore the index of happiness (HPI) in the studied countries. The Netherlands is ranked 18th out of 140 in the ranking of the "happiest" countries in the world and 3rd among the EU countries, behind Norway and Spain [10]. Also, this state recorded the lowest level of economic inequality, which is $4 \%$, among all countries. Unlike the Netherlands, the HPI in France and Belgium shows low rates. In total, according to all the criteria of this indicator, France occupies 40th position, and Belgium - 87th. Therefore, choosing countries of destination, migrants are most likely guided by various reasons.

The number of asylum seekers in EU Member States in 2019 increased by $11.2 \%$ compared to 2018. In contrast to Belgium and the Netherlands, in France from 2008 to 2018, this figure almost tripled, and the share of asylum seekers among all immigrants in the country was $31 \%$. France is the second EU destination country for asylum seekers and refugees after Germany. In 2019, France became the host country for the majority of refugees from Afghanistan, Albania, Georgia, Genoa and Bangladesh. The main reasons of emigration for asylum seekers are the political situation in their home countries, domestic violence, and sexual harassment.

Belgium registered a significantly lower number of asylum seekers than France during 2009-2019. For comparison, in 2019 the share of refugees in France was $19.6 \%$ of all refugees in the EU, while in Belgium $-3.8 \%$, and in the Netherlands $-3.7 \%$. This

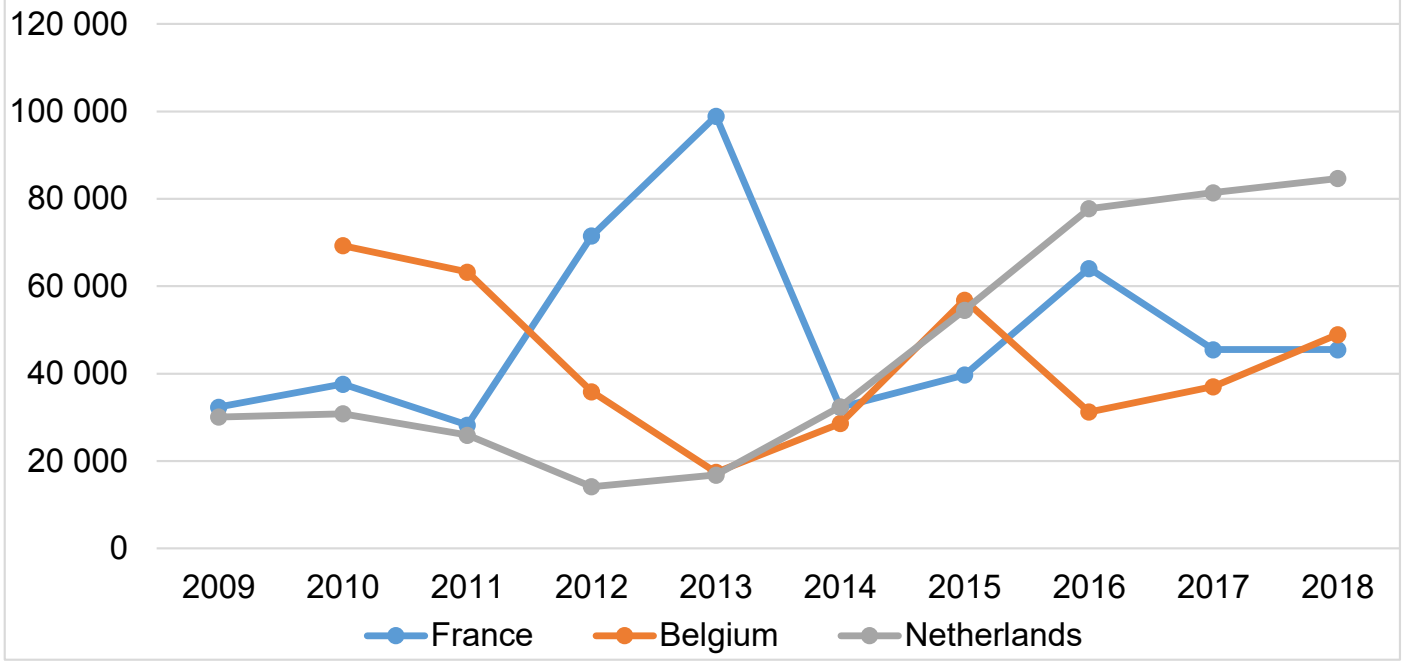

Figure 1. Net migration in selected EU countries in 2009-2018, number 
is because of the fact that it is much more difficult to obtain asylum in Belgium. The country is dominated by refugees from Syria, Palestine, Afghanistan, El Salvador and Eritrea. Firstly, Belgium attracts asylum seekers with its political stability. Secondly, since 2019, it has a new rule, according to which refugees can officially find employment, even if their application for asylum has not been approved by the Office of the Commissioner General for Refugees and Stateless Persons in Belgium yet.

In 2019, the number of asylum seekers in the Netherlands increased by only $5 \%$ compared to the previous year. Significant groups of asylum seekers are natives of Syria, Nigeria, Iran, Turkey and Algeria. The Netherlands attracts asylum seekers mostly with its social security system, which allows refugees to have absolutely the same rights as native people.

The largest percentage of immigrants who found employment in the country of destination has been recorded in the Netherlands (Figure 2). Despite the fact that in 2019 the average value of this indicator throughout the country was $71.1 \%$, in the Dutch province of Flevoland it was the highest in the EU 92.7\%. Compared to other EU Member States, it is not high enough. For instance, in the Czech Republic 86.1\% of European immigrants found a job, in Iceland -90\%, and in Malta - 91\% in 2019. For this indicator, France ranks 24th among EU countries and is ahead of only Greece (29.5\%), Hungary (58.4\%) and Italy (62.4\%).

In general, the smallest difference in the percentage of labor migrants from the EU countries and labor migrants from non-EU members is observed in France - throughout the entire period it has varied within $8.4-15 \%$. In the Netherlands, the situation was more stable, the indicator was in the range of 10-14\% in 2009-2019. The greatest differentiation was recorded in Belgium (20-28\%), from which it follows that in this country it is much more difficult for migrants from non-EU states to find a job than for migrants from the EU Member States. This situation may indicate the fact of discrimination.

Since one of the drivers of immigration to France, Belgium and the Netherlands is the creation of own business in more favorable conditions for an entrepreneur, it would be appropriate to consider in more detail the proportion of people who work for themselves. Interestingly, the percentage of self-employed migrants from other EU countries in France, Belgium and the Netherlands prevails over the percentage of self-employed natives. Since in the modern world labor migration within Europe is practiced more often, in principle this phenomenon is normal. On the other hand, it may indicate that these countries have a more favorable and attractive business climate, and more migrants from neighboring European countries immigrate here. The Netherlands is a leading country by this criterion, as almost $1 / 5$ of European migrants are selfemployed, which is a fairly good result. In 2018, the top countries with the largest percentage of selfemployed migrants from other EU Member States were led by Poland (38\%), ahead of Malta (21\%) and Estonia (20\%). The highest level of self-employment among migrants arriving from non-EU countries was in the Czech Republic (35\%) and in Poland (19\%). The predominant percentage of local people working for themselves was noted in Greece (31\%) and Italy (22\%). The average rate of self-employed migrants across the EU who came from other non-EU states was 11.8\% in 2019 (in Belgium it is lower - 11.3\%), for migrants from the EU countries - $11.5 \%$ (in France $11.4 \%$ ), and for indigenous people $-13.8 \%$.

In recent years, there has been a downward trend in the unemployment rate, which has a positive effect on the economies. The Netherlands has one of the lowest unemployment rates among all the EU countries, while in France, on the contrary, this

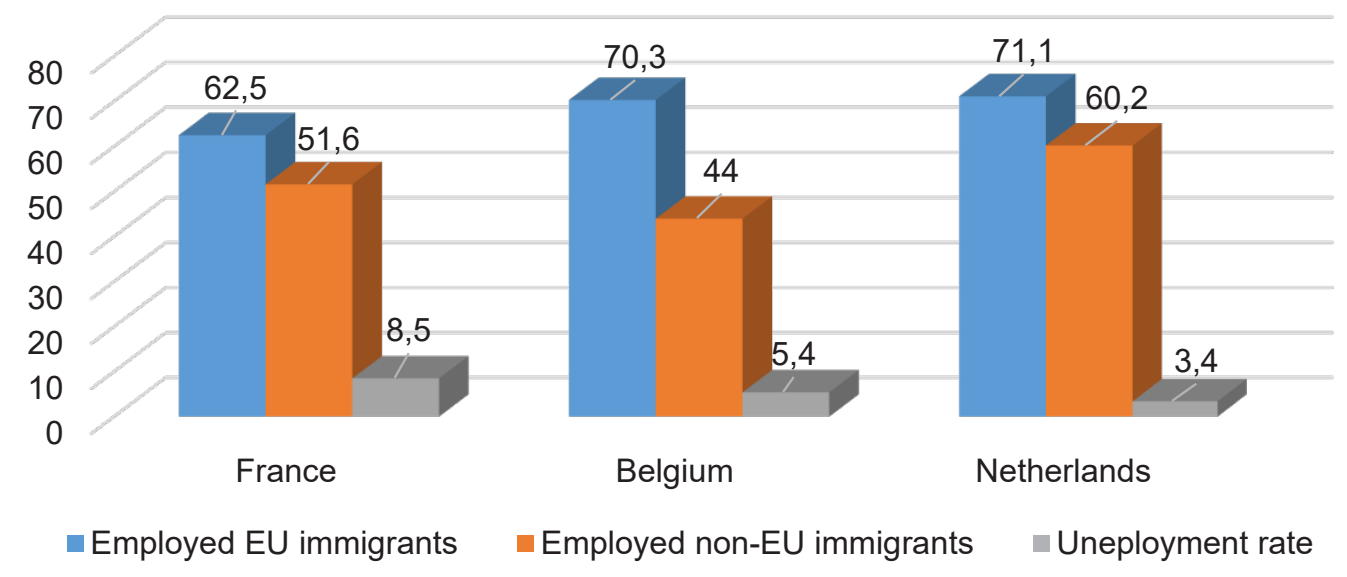

Figure 2. Employment rate and unemployment rate in France, Belgium and the Netherlands in 2019, \% Source: [8; 9] 


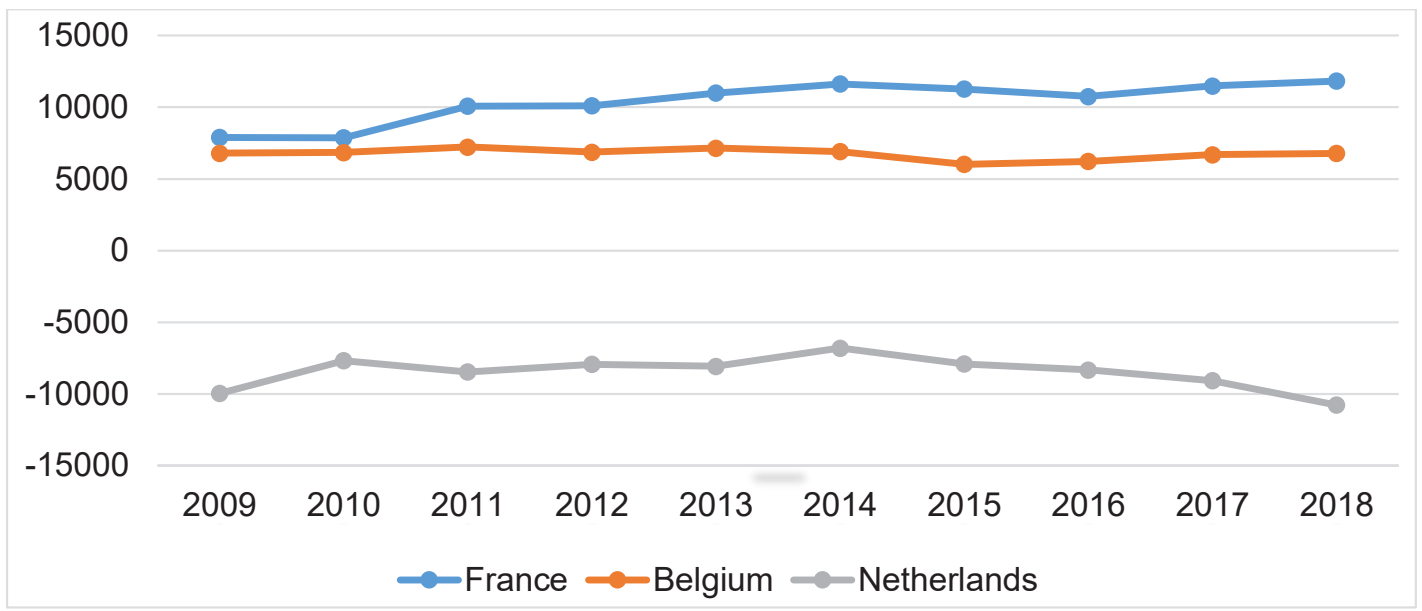

Figure 3. Net personal remittances of the selected EU countries, million USD

Source: [9]

figure in some periods exceeded the unemployment rate in the EU and the Eurozone. Moreover, the unemployment rate among immigrants in France, Belgium and the Netherlands is higher than the one among the local population. However, the Netherlands can boast that the unemployment rate among immigrants from non-EU countries is almost equal to the unemployment rate among the Dutch population. This point to the fact that the authorities in the Netherlands provide employment opportunities and equal rights to migrants as to their native people. In Belgium, the unemployment rate is quite low (5.4\%) compared to the EU, but among immigrants from non-EU Member States this indicator is almost 3 times higher (14\%). However, the unemployment rate among immigrants from other EU countries is almost equal to that one among the indigenous population of Belgium.

An important aspect in the analysis of migration processes is the remittances of migrants, which influence on both the host country and the homeland. Remittances help to stimulate demand in the receiving country, its further economic growth, and have a positive effect on its tax base. Each year, their amounts increase so much that, for example, in 2019, remittances to Montenegro were estimated at $25.4 \%$ of GDP, to Moldova - 16.3\%, to Georgia - 14.2\%. First of all, remittances play a significant role in the economies of developing countries. However, in developed states their amounts are small in relation to GDP, for example, in Belgium they amounted to $2.5 \%$ of GDP, in France - 1\%, and in the Netherlands $0.3 \%$ in 2019.

France tops the list of countries in terms of the largest outward remittance flows, mainly directed to African countries. Compared to the beginning of the analyzed period, this indicator increased by $30 \%$ (from 11.8 billion USD to 15.2 billion USD). The decrease in transaction costs from $40 \%$ in 2013 to $6.6 \%$ in 2019 also influenced the increase in remittances from
France [11]. Recipients mainly spend this money on food, education and health (70-80\% of the total), but investments account for less than $10 \%$, therefore, remittances do not have a significant impact on improving the economy of the receiving countries, since the money is simply consumed.

Remittances sent by Belgians to their country increased by $14.3 \%$ in 2019 compared to 2009 , but from Belgium abroad - by $29 \%$. The main obstacle in the implementation of this process for migrants is the too high cost of sending money (on average $7-9.5 \%$ of the total amount) from the host country to their homeland. The amount of remittances that developing countries have received from their emigrants in Belgium exceeds three times the amount that the country allocates to them as official development assistance. On the other hand, since Belgium is the net recipient of remittances, the primary income in the balance of payments has always been positive. However, over the past five years, there has been a trend towards a decrease in the balance of primary income (from 6.6 billion USD to 634.4 million USD) [12]. While the amount of remittances flowing into Belgium is growing, so are the payments of investment income, which exceed their receipts.

Unlike France and Belgium, the Netherlands has a negative net remittance value, as migrants send significantly more money back to their homeland than the Dutch (Figure 3). The remittances that the Dutch send to the Netherlands from other countries do not have a strong impact on the state of its balance of payments, in particular on the balance of primary income, since the investment income in the Netherlands significantly exceeds their payments, which ultimately contributes to a positive balance of primary income.

Conclusions. Over the past 10 years, migration processes have led to an even greater integration of countries, especially European ones, since the flows of immigrants have increased by an average of 30\% 
during this time. The analyzed EU Member States, particularly France, Belgium and the Netherlands are attractive for migrants as destination countries since their macroeconomic indicators show some of the highest values among the $\mathrm{EU}$, and their migration policy is constantly evolving, thereby providing more favorable conditions for immigrants.

Despite the fact that the selected EU countries recorded a high level of employment, on average, only $68 \%$ of European immigrants and only half of migrants who arrived from non-European countries found work. Nevertheless, the Netherlands ensures equal conditions for native and migrant entrepreneurs, as evidenced by the case that in this country $18.5 \%$ of European migrants are self-employed, while among indigenous people this percentage is 16.5 .

This study confirms the fact that migrant remittances are an integral part of the analysis of migration processes, as they influence the economies of both destination and host countries, affecting their balance of payments and final consumption. France and Belgium are net recipients of remittances, while the Netherlands is a net sender. Although, annually from these EU countries, migrants send large amounts of money, this does not stimulate economic growth in the receiving countries, since $70-80 \%$ of remittances are spent on meeting necessary needs and only $10 \%$ are invested.

\section{REFERENCES:}

1. Kahanec M., Pyltikova M. (2016) The Economic Impact of East-West Migration on the European Union. IZA Discussion Paper, no. 10381. Available at: https://ssrn.com/abstract=2879788 (accessed 15 January 2021).

2. Orrenius P.M., Zavodny M. (2016) Irregular Immigration in the European Union. FRB of Dallas Working Paper, no. 1603. Available at: https://papers.ssrn.com/sol3/ papers.cfm?abstract id=2736160\# (accessed $15 \mathrm{Ja}$ nuary 2021).

3. Strockmeijer A., Beer P., Dagevos J. (2019) Should I stay or should I go? What we can learn from working patterns of Central and Easter European labour migrants about the nature of present-day migration. Journal of Ethic and Migration Sudies, vol. 45, no. 13 , pp. 2430-2446. DOI: https://doi.org/10.1080/1369183X. 2018.1562326 (accessed 15 January 2021).

4. Dominese G., Yakubovskiy S., Tsevukh J., Rodionova T. (2020) Impact of International Migration Flows on the European Union and Ukraine. Journal Transition Studies Review, vol. 27, no. 2, pp. 83-98. DOI: https://doi.org/10.14665/1614-4007-27-2-007 (accessed 15 January 2021).

5. Tsevukh J.O., Yakubivskiy S.O. (2017) Mizhnarodna migratsiya robochoi sili yak chinnik ekonomichnogo rozvitku krain [International labor migration as a factor of economic development of countries]. Odesa: ONU. 274p. (in Ukrainian)

6. Kachanovska M., Yakubovskiy S. (2020) Influence of the Covid-19 Pandemic on the Economic Relations of Ukraine with Latvia, Lithuania and Estonia. Relevant trends of scientific research in the countries of Central and Eastern Europe (Latvia, Riga, November 20, 2020), Riga: Baltija Publishing, pp.90-93. Available at: http://www.baltijapublishing.Iv/omp/index.php/bp/catalog/download/78/1883/4130-1 ?inline=1 (accessed 15 January 2021).

7. Yakubovskiy S.O., Kachanovska M.S. (2020) Ekonomichni ryzyky trudovoi mihratsii dlia Ukrainy $\mathrm{v}$ umovakh pandemii Covid-19 [Economic risks of labor migration for Ukraine in the during the Covid-19 pandemic]. Mizhnarodni vidnosyny (electronic journal), no. 23, pp. 123-125. Available at: http://journals.iir.kiev.ual index.php/ec_n/article/view/4078 (accessed 15 January 2021). (in Ukrainian)

8. The World Bank (2021) Economic indicators. Available at: https://data.worldbank.org/indicator (accessed 15 January 2021).

9. Eurostat (2020) Migration Data Available at: https://ec.europa.eu/eurostat/web/main/home (accessed 15 January 2021).

10. Happy Planet Index (2021) Available at: http://happyplanetindex.org/countries (accessed 15 January 2021).

11. Global Partnership for Financial Inclusion (2019) G-20 National Remittance Plan - France. Available at: https://www.gpfi.org/sites/gpfi/files/sites/default/files/Fra nce\%20National\%20Remittance\%20Plan\%202019.pdf (accessed 20 January 2021).

12. International Monetary Fund (2021) Balance of Payments. Available at: https://data.imf.org/?sk= 7A51304B-6426-40C0-83DD-CA473CA1FD52\&sId=13 90030341854 (accessed 20 January 2021).

\section{БІБЛІОГРАФІЧНИЙ СПИСОК:}

1. Kahanec M., Pyltikova M. The Economic Impact of East-West Migration on the European Union. IZA Discussion Paper. 2016. № 10381. URL: https://ssrn. com/abstract=2879788 (дата звернення: 15.01.2021).

2. Orrenius P.M., Zavodny M. Irregular Immigration in the European Union. FRB of Dallas Working Paper. 2016. № 1603. URL: https://papers.ssrn.com/ sol3/papers.cfm?abstract id=2736160\# (дата звернення: 15.01.2021)

3. Strockmeijer A., Beer P., Dagevos J. Should I stay or should I go? What we can learn from working patterns of Central and Easter European labour migrants about the nature of present-day migration. Journal of Ethic and Migration Sudies. 2019. Vol. 45, no. 13, pp. 2430-2446. DOI: https://doi.org/10.1080/1369183X.2018.1562326 (дата звернення: 15.01.2021).

4. Dominese G., Yakubovskiy S., Tsevukh J., Rodionova T. Impact of International Migration Flows on the European Union and Ukraine. Journal Transition Studies Review. 2020. Vol. 27, no. 2, pp. 83-98. DOI: https://doi.org/10.14665/1614-4007-27-2-007 (дата звернення: 15.01.2021).

5. Цевух Ю.О., Якубовський С.О. Міжнародна міграція робочої сили як чинник економічного розвитку країн: монограсрія. Одеса : ОНУ, 2017. 274 с.

6. Kachanovska M., Yakubovskiy S. (2020) Influence of the Covid-19 Pandemic on the Economic Relations of Ukraine with Latvia, Lithuania and Estonia. 
Relevant trends of scientific research in the countries of Central and Eastern Europe (Latvia, Riga, November 20, 2020), Riga: Baltija Publishing, pp. 90-93. URL: http://www.baltijapublishing.Iv/omp/index.php/bp/catalog/download/78/1883/4130-1?inline=1 (дата звернен-/ ня: 15.01.2021).

7. Якубовський С.О., Качановська М.С. Економічні ризики трудової міграції для України в умовах пандемії Covid-19. Міжнародні відносини (електронний журнал). № 23. С. 123-125. URL: http://journals.iir.kiev.ua/index.php/ec_n/article/view/ 4078 (дата звернення: 15.01.2021).

8. The World Bank. Economic indicators. 2021. URL: https://data.worldbank.org/indicator (дата звернення: 15.01.2021).
9. Eurostat. Migration Data. 2020. URL: https://ec.europa.eu/eurostat/web/main/home (дата звернення: 15.01.2021).

10. Happy Planet Index. 2021. URL: http://happyplanetindex.org/countries (дата звернення: 15.01.2021).

11. Global Partnership for Financial Inclusion (2019) G-20 National Remittance Plan - France. URL: https://www.gpfi.org/sites/gpfi/files/sites/default/files/ France\%20National\%20Remittance\%20Plan\%202019. pdf (дата звернення: 20.01.2021).

12. International Monetary Fund. Balance of Payments. 2021. URL: https://data.imf.org/?sk=7A51304B -6426-40C0-83DD-CA473CA1FD52\&sld=13900 30341854 (дата звернення: 20.01.2021). 